\title{
New records and range expansion of Calosoma sycophanta (Linnaeus, 1758) (Coleoptera, Carabidae) in Western Siberia, Russia
}

\author{
Vitaly A. Stolbov ${ }^{1}$, Igor V. Kuzmin ${ }^{1}$, Dmitry E. Lomakin ${ }^{1}$, Sergei A. Ivanov ${ }^{1}$, Pavel S. Sitnikov ${ }^{2}$
}

1 Tyumen State University, 6 Volodarskogo St., 625003 Tyumen, Russia. 2 The Tyumen branch of the All-Russian Society for the Conservation of Nature, 33 Odesskaya St., 625000 Tyumen, Russia.

Corresponding author: Vitaly A. Stolbov, vitusstgu@mail.ru

\begin{abstract}
In this study, we report about 25 records of Calosoma sycophanta (Linnaeus, 1758) from Western Siberia collected in the last 21 years (1997-2017). We extend the known distribution of this species in the Tyumen, Kurgan, Omsk and Novosibirsk regions of Russia. New records extend the known distribution of C. sycophanta for $300 \mathrm{~km}$ to the north, and for $600 \mathrm{~km}$ to the east, in the Western Siberia. These new distributional data may contribute to a re-evaluation of its conservation status.
\end{abstract}

Key words

Biogeography; climate change.

Academic editor: Bruno Clarkson | Received 11 June 2018 | Accepted 21 August 2018 | Published 7 September 2018

Citation: Stolbov VA, Kuzmin IV, Lomakin DE, Ivanov SA, Sitnikov PS (2018) New records and range expansion of Calosoma sycophanta (Linnaeus, 1758) (Coleoptera, Carabidae) in Western Siberia, Russia. Check List 14 (5): 731-736. https://doi.org/10.15560/14.5.731

\section{Introduction}

The forest caterpillar hunter, Calosoma sycophanta (Linnaeus, 1758) (Figs 1, 2), a member of the family Carabidae, is distributed in the Western Palearctic. The range of this species covers the whole of Europe, northwest Africa, Western and Central Asia (Kryzhanovsky 1981, Kryzhanovsky et al. 1995, Kryzhanovsky and Obydov 2001, Bespalov et al. 2010).

This entomophagus predator has been introduced in North America for forest pest control, where it has successfully established and is now expanding its range (Evans 2009). In some countries it is reproducing very successful (Kanat and Mol 2008). Despite this, in many countries and regions (e.g. Czech Republic, Poland, Germany, Russia, Ukraine and Azerbaijan), populations of this beetle are small and continue to decline, and in these counties, this species is protected. Due to its large size, bright color, practical significance, and conservation value, this species of beetle is well-known.

The north-eastern border of the Asian part of the area is currently not well-known (Bespalov et al. 2010). By the 1990s, C. sycophanta was located along the southern Ural Mountains and in western Kazakhstan (Kryzhanovsky 1981, 1983), where it is still relatively common (Yashchenko and Mityaev 2005, E.V. Zinoviev 2018 pers. comm.). The northernmost specimens were found in the central Ural Mountains (Sverdlovsk oblast) between 1989 and 1996 in the vicinity of the cities of Asbest, Yekaterinburg, Belorechensk (Fig. 3) (Voronin 1999). The easternmost specimens were found in the southwest of Western Siberia in the Trans-Ural regions (Kurgan oblast) (Kalinin 1985, Molchanov 1989, Utkin 1999, 

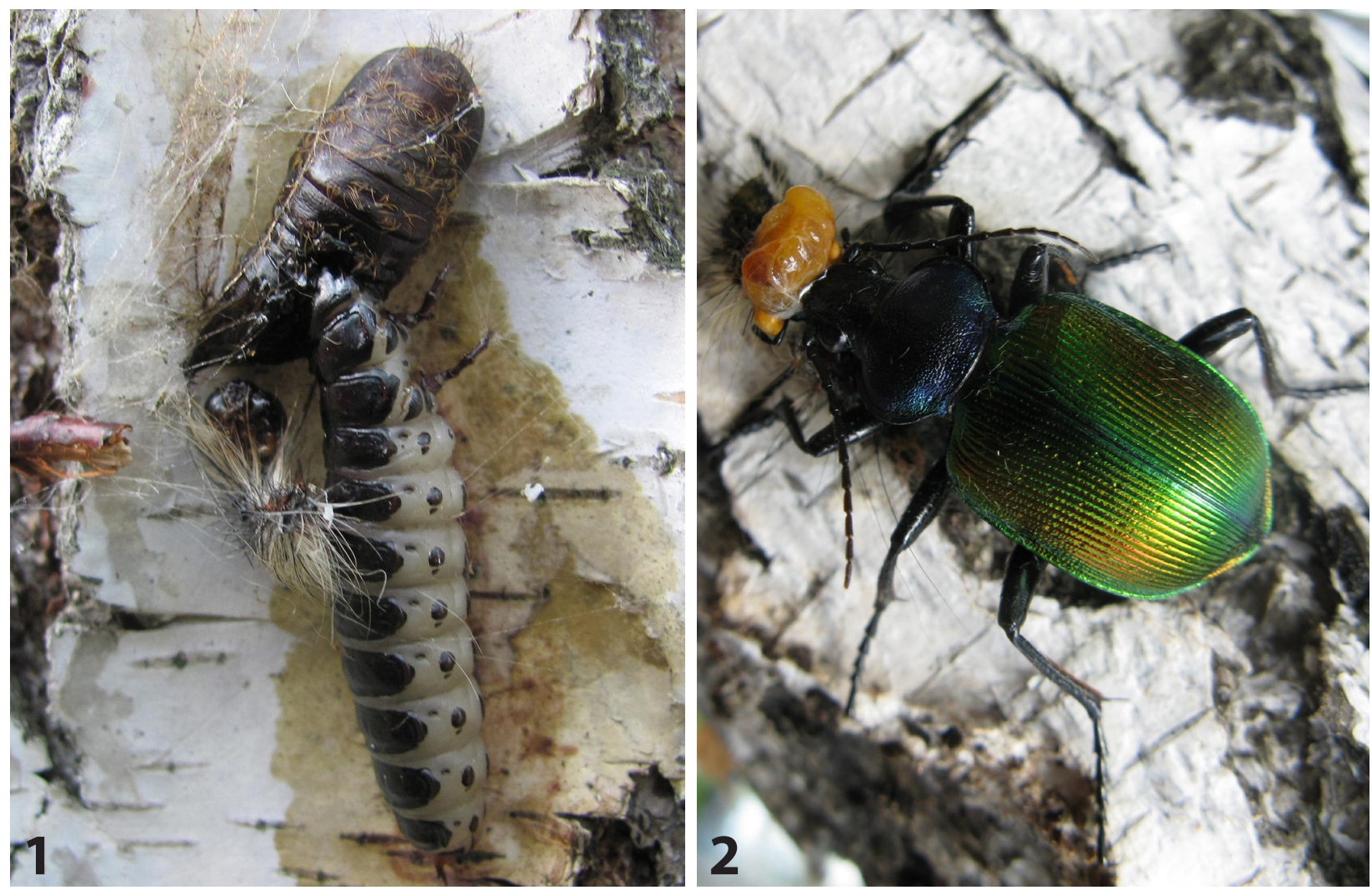

Figures 1, 2. Calosoma sycophanta. 1. Larvae, Uporovsky district of Tyumen oblast (record no. 21), photography by V.A. Sannikov. 2. Female, Kazansky district of Tyumen oblast (record no. 18), photography by A.S. Aphonin.

Utkin and Balahonova 2012). The south-eastern border of the area is formed by the mountains of Central Asia. In the east, the distribution of C. sycophanta is limited to northeastern Kazakhstan, northwestern Mongolia, and a southwestern Altai within Russia (Jacobson 1905-1915, Breuning 1927, Kryzhanovsky 1981, 1983, Kryzhanovsky and Obydov, 2001, Bespalov et al. 2010). The latest records of $C$. sycophanta in Altai Krai (Zmeinogorsky district) were found in 1990 and 2001 (Obydov 2010) (Fig. 3). Calosoma sycophanta was not found in the dry steppes and deserts of central Kazakhstan. Thus, in the Asian part of its range, this species area occurs in 2 areas - a northern area, running through the southern Ural Mountains and Western Siberia, and a southern area, which includes the mountainous regions of Central Asia, Altai, and northwestern Mongolia (Fig. 3, inset).

However, since the late 1990s there has been a large number of new records of this species in the territory of Western Siberia, including some from a considerable distance from its previously known range. These records were partially published in various local and regional natural history journals. An annotated list of all records, both new and previously published, and a discussion of possible reasons for the increase in the number and expansion of the area of C. sycophanta in the Asian part of Russia is given below.

\section{Methods}

We studied the collections of the Zoological Museum of Tyumen State University (Tyumen), the Museum
Complex of Slovtsov (Tyumen), the Siberian Zoological Museum (Novosibirsk), private collections of M.A. Ananin and A.V. Litvinov (both amateur entomologists), and photographs and observations by local residents and naturalists. All literature was critically examined. The originals of rare and difficult-to-find publications were especially searched for.

Of the new material that we collected, most of the specimens were collected by hand. In some cases, beetles were caught in soil traps and cages with gypsy moth larvae. For some, only typical fragments of sclerotised elytra were found.

\section{Results}

Records. All records of Calosoma sycophanta in Western Siberia from the last 21 years (1997-2017) are listed in chronological order in Table 1. Many of the records were previously published, but mostly in local natural history journals and often with incomplete data. Other records are new, published here for the first time. Figure 3 maps these records; numbers correspond to records in Table 1.

Identification. Body length is $21-33 \mathrm{~mm}$. Head and pronotum dark blue or blue-green. Elytra golden-green with copper-red tint, sometimes copper-red. Antennae and legs black. Wings are developed, capable of flying. The color of this species differs from other species Calosoma in Eurasia. 
Table 1. Summary of the records of Calosoma sycophanta (L., 1758) in Western Siberia, Russia, 1997-2017. Datum for geographic coordinates: WGS84.

\begin{tabular}{|c|c|c|c|c|c|c|c|}
\hline No. & Date & Location & Latitude & Longitude & $\begin{array}{l}\text { Altitude } \\
\text { (m) }\end{array}$ & Observation & Source \\
\hline 1 & 24 Jun. 1997 & $\begin{array}{l}\text { Kurgan Oblast, Polovinsky } \\
\text { District, Sumki Village }\end{array}$ & $55^{\circ} 03^{\prime} \mathrm{N}$ & $065^{\circ} 44^{\prime} \mathrm{E}$ & 155 & 1 male, N. Selutina coll. & $\begin{array}{l}\text { Siberian Zoological Museum } \\
\text { (Novosibirsk), Bespalov et al. } \\
2010\end{array}$ \\
\hline 2 & $\begin{array}{l}\text { Summer } \\
1997\end{array}$ & $\begin{array}{l}\text { Tyumen Obl., Sladkovsky Distr., } \\
\text { Menzhinskoye Vill. }\end{array}$ & $55^{\circ} 46^{\prime} \mathrm{N}$ & $069^{\circ} 52^{\prime} \mathrm{E}$ & 135 & $\begin{array}{l}1 \text { female, M.S. Ananin } \\
\text { coll. }\end{array}$ & Gashev et al. 2002 \\
\hline 3 & $\begin{array}{l}\text { Summer } \\
1998-1999\end{array}$ & $\begin{array}{l}\text { Tyumen Obl., Ishimsky Distr., } \\
\text { Sinitsyna Vill. }\end{array}$ & $56^{\circ} 00^{\prime} \mathrm{N}$ & $069^{\circ} 28^{\prime} \mathrm{E}$ & 80 & 1 imago, Students coll. & $\begin{array}{l}\text { Gashev et al. 2002, Levykh } \\
2003\end{array}$ \\
\hline 4 & 6 Jul. 1999 & $\begin{array}{l}\text { Tyumen Obl., Ishimsky Distr., } \\
\text { Bykova Vill. }\end{array}$ & $56^{\circ} 03^{\prime} \mathrm{N}$ & $069^{\circ} 16^{\prime} \mathrm{E}$ & 85 & 1 male, Kuydina coll. & $\begin{array}{l}\text { Museum Complex of Slovtsov } \\
\text { (Tyumen), Lomakin et al. 2001, } \\
\text { Levykh } 2003\end{array}$ \\
\hline 5 & 17 Jun. 2000 & $\begin{array}{l}\text { Tyumen Obl., Isetsky Distr., the } \\
\text { Rafailovsky Nature Reserve, } \\
\text { Olkhovka River }\end{array}$ & $56^{\circ} 24^{\prime} \mathrm{N}$ & $065^{\circ} 11^{\prime} \mathrm{E}$ & 75 & $\begin{array}{l}\text { Forest glade, part of the } \\
\text { elytra on the ground, I.P. } \\
\text { Sitnikov coll. }\end{array}$ & $\begin{array}{l}\text { Museum Complex of Slovtsov } \\
\text { (Tyumen), Lomakin et al. 2001, } \\
\text { Gashev et al. } 2002\end{array}$ \\
\hline 6. & July 2000 & $\begin{array}{l}\text { Tyumen Obl., Tyumen Distr., } \\
\text { Bogandinskiy Settlement }\end{array}$ & $56^{\circ} 52^{\prime} \mathrm{N}$ & $065^{\circ} 50^{\prime} \mathrm{E}$ & 73 & $\begin{array}{l}\text { Forest edge, } 2 \text { imago, } \\
\text { A.V. Litvinov coll. }\end{array}$ & $\begin{array}{l}\text { A.V. Litvinov private collection, } \\
\text { new record }\end{array}$ \\
\hline 7 & 12 Jul. 2001 & Tyumen Obl., Ishim City & $56^{\circ} 06^{\prime} \mathrm{N}$ & $069^{\circ} 28^{\prime} \mathrm{E}$ & 84 & $\begin{array}{l}\text { City park, } 1 \text { imago, } \\
\text { Anonymous coll. }\end{array}$ & Gashev et al. 2002 \\
\hline 8 & $\begin{array}{l}3-21 \text { Jul. } \\
2001\end{array}$ & $\begin{array}{l}\text { Altai Krai, Zmeinogorsky Distr., } \\
\text { Cherepanovsk Settl. }\end{array}$ & $51^{\circ} 11^{\prime} \mathrm{N}$ & $082^{\circ} 19^{\prime} \mathrm{E}$ & 430 & $\begin{array}{l}2 \text { female, D.V. Obydov } \\
\text { and I. Chernyshev coll. }\end{array}$ & $\begin{array}{l}\text { Moscow Biological Museum, } \\
\text { Obydov } 2010\end{array}$ \\
\hline 9 & July 2004 & Tyumen Obl., Yurginskoye Vill. & $56^{\circ} 49^{\prime} \mathrm{N}$ & $067^{\circ} 23^{\prime} \mathrm{E}$ & 105 & $\begin{array}{l}1 \text { female, M. Trofimova } \\
\text { Coll. }\end{array}$ & $\begin{array}{l}\text { Zoological Museum of Tyumen } \\
\text { State University, Tolstikov 2004, } \\
\text { Tolstikov et al. } 2013\end{array}$ \\
\hline 10 & 08 Jul. 2006 & $\begin{array}{l}\text { Tyumen Obl., Omutinsky Distr., } \\
200 \text { m W Zhuravlevskoye Vill. }\end{array}$ & $56^{\circ} 16^{\prime} \mathrm{N}$ & $067^{\circ} 40^{\prime} \mathrm{E}$ & 129 & $\begin{array}{l}\text { Birch forest, } 1 \text { female, A.I. } \\
\text { Levchenko photos }\end{array}$ & $\begin{array}{l}\text { Sitnikov 2013, A.I. Levchenko } \\
\text { pers. comm. } 2013\end{array}$ \\
\hline 11 & $\begin{array}{l}\text { Summer } \\
2007\end{array}$ & $\begin{array}{l}\text { Tyumen Obl., Golyshmanovsky } \\
\text { Distr., Razhevo Vill. }\end{array}$ & $56^{\circ} 09^{\prime} \mathrm{N}$ & $068^{\circ} 23^{\prime} \mathrm{E}$ & 113 & $\begin{array}{l}\text { Small birch forest in a } \\
\text { field (kolok), } 1 \text { imago, } \\
\text { D.V. Kalinin photo }\end{array}$ & $\begin{array}{l}\text { I.E. Niznik and D.V. Kalinin pers. } \\
\text { comm. 2018, new record }\end{array}$ \\
\hline 12 & 05 Jul. 2009 & $\begin{array}{l}\text { Omsk Obl., Gorkovsky Distr, } 3 \\
\text { km NE Alekseyevskiy Settl. }\end{array}$ & $55^{\circ} 33^{\prime} \mathrm{N}$ & $074^{\circ} 06^{\prime} \mathrm{E}$ & 114 & $\begin{array}{l}\text { Aspen forest, } 1 \text { imago, } \\
\text { S.A. Knyazev Coll. }\end{array}$ & Knyazev 2015 \\
\hline 13 & 20 Jun. 2010 & $\begin{array}{l}\text { Novosibirsk Obl., Karasuksky } \\
\text { Distr., } 20 \text { km SW Karasuk City }\end{array}$ & $53^{\circ} 36^{\prime} \mathrm{N}$ & $077^{\circ} 50^{\prime} \mathrm{E}$ & 107 & $\begin{array}{l}\text { Small birch forest in } \\
\text { a field (kolok), in the } \\
\text { cage with caterpillars } \\
\text { Lymantria dispar, } 1 \text { male, } \\
\text { V.V. Martemyanov coll. }\end{array}$ & $\begin{array}{l}\text { Siberian Zoological Museum } \\
\text { (Novosibirsk), Bespalov et al. } \\
2010\end{array}$ \\
\hline 14 & 03 Jul. 2011 & $\begin{array}{l}\text { Tyumen Obl., Armizonsky Distr., } \\
\text { Prokhorovo Vill. }\end{array}$ & $55^{\circ} 55^{\prime} \mathrm{N}$ & $067^{\circ} 24^{\prime} \mathrm{E}$ & 138 & $\begin{array}{l}1 \text { imago, K. Kurochkina } \\
\text { photo }\end{array}$ & $\begin{array}{l}\text { K. Kurochkina pers. comm. } \\
\text { 2017, new record }\end{array}$ \\
\hline 15 & 20 Jun. 2012 & $\begin{array}{l}\text { Tyumen Obl., Kazansky Distr., } \\
1500 \text { m N Gagarye Vill. }\end{array}$ & $55^{\circ} 45^{\prime} \mathrm{N}$ & $069^{\circ} 16^{\prime} \mathrm{E}$ & 76 & $\begin{array}{l}\text { Small wet birch forest } \\
\text { with common reed in a } \\
\text { field (kolok), } 1 \text { imago, I. } \\
\text { Kaempf, W. Mathar, S.S. } \\
\text { Tupitzin photos }\end{array}$ & $\begin{array}{l}\text { W. Mathar and S.S. Tupitzin } \\
\text { pers. comm. 2016, new record }\end{array}$ \\
\hline 16 & 23 Jun. 2014 & $\begin{array}{l}\text { Omsk Obl., Cherlaksky Distr., } 2 \\
\text { km NE Berdnikovo Vill. }\end{array}$ & $54^{\circ} 26^{\prime} \mathrm{N}$ & $074^{\circ} 28^{\prime} \mathrm{E}$ & 111 & $\begin{array}{l}\text { Cottonwood field wind- } \\
\text { breaks, badly damaged } \\
\text { by caterpillars } L \text {. dispar, } 1 \\
\text { imago, S.A. Knyazev coll. }\end{array}$ & Knyazev 2015 \\
\hline 17 & $\begin{array}{l}\text { 23-26 Jun. } \\
2014\end{array}$ & $\begin{array}{l}\text { Novosibirsk Obl., Karasuksky } \\
\text { Distr., } 7 \text { km W Troitskoye Vill. }\end{array}$ & $53^{\circ} 43^{\prime} \mathrm{N}$ & $077^{\circ} 41^{\prime} \mathrm{E}$ & 109 & $\begin{array}{l}\text { Small birch forest in } \\
\text { a field (kolok), during } \\
\text { the mass outbreak } \\
\text { of } L \text {. dispar, soil traps, } \\
\text { more than } 20 \text { imago, I.I. } \\
\text { Lyubechanskiy and G.N. } \\
\text { Azarkina coll. }\end{array}$ & $\begin{array}{l}\text { Siberian Zoological Museum } \\
\text { (Novosibirsk), I.I. Lyubechan- } \\
\text { skiy pers. comm. 2017, new } \\
\text { unpublished record }\end{array}$ \\
\hline 18 & 3 Jul. 2014 & $\begin{array}{l}\text { Tyumen Obl., Kazansky Distr., } 5 \\
\text { km E Kazanskoye Vill. }\end{array}$ & $55^{\circ} 39^{\prime} \mathrm{N}$ & $069^{\circ} 19^{\prime} \mathrm{E}$ & 83 & $\begin{array}{l}\text { Small birch forest in a } \\
\text { field (kolok), numerous } \\
\text { imago and larvae, A.S. } \\
\text { Afonin photos }\end{array}$ & $\begin{array}{l}\text { A.S. Afonin pers. comm. 2017, } \\
\text { new record }\end{array}$ \\
\hline 19 & 20 Jun. 2015 & $\begin{array}{l}\text { Tyumen Obl., Uporovsky Distr., } \\
1300 \text { m E Masali Vill. }\end{array}$ & $56^{\circ} 04^{\prime} \mathrm{N}$ & $66^{\circ} 35^{\prime} \mathrm{E}$ & 132 & $\begin{array}{l}\text { Dry birch forest, } 2 \\
\text { imago (incl. } 1 \text { male), N.V. } \\
\text { Khozyainova Coll. and } \\
\text { E.S. Bayanov photos }\end{array}$ & $\begin{array}{l}\text { Zoological Museum of Tyumen } \\
\text { State University, Bayanov and } \\
\text { Khozyainova } 2015\end{array}$ \\
\hline 20 & 29 Jun. 2015 & $\begin{array}{l}\text { Tyumen Obl., Omutinsky Distr., } \\
\text { Sitnikovo Vill. }\end{array}$ & $56^{\circ} 21^{\prime} \mathrm{N}$ & $67^{\circ} 50^{\prime} \mathrm{E}$ & 109 & $\begin{array}{l}\text { In the courtyard of a rural } \\
\text { school, } 1 \text { female, S.A. } \\
\text { Semyonova photo }\end{array}$ & $\begin{array}{l}\text { E.S. Bayanov and A.I. } \\
\text { Levchenko pers. comm. 2015, } \\
\text { new record }\end{array}$ \\
\hline 21 & 1 Jul. 2015 & $\begin{array}{l}\text { Tyumen Obl., Uporovsky Distr., } \\
4.5 \text { km NW Berdyugino Vill. }\end{array}$ & $56^{\circ} 11^{\prime} \mathrm{N}$ & $66^{\circ} 23^{\prime} \mathrm{E}$ & 129 & $\begin{array}{l}\text { Birch forest, } 1 \text { larva, V.A. } \\
\text { Sannikov photo }\end{array}$ & $\begin{array}{l}\text { I.E. Niznik and V.A. Sannikov } \\
\text { pers. comm. 2018, new record }\end{array}$ \\
\hline 22 & 2 Jul. 2015 & $\begin{array}{l}\text { Tyumen Obl., Sladkovsky Distr., } \\
\text { Menzhinskoye Vill. }\end{array}$ & $55^{\circ} 46^{\prime} \mathrm{N}$ & $69^{\circ} 52^{\prime} \mathrm{E}$ & 135 & $\begin{array}{l}1 \text { imago, M.S. Ananin } \\
\text { photo }\end{array}$ & $\begin{array}{l}\text { M.S. Ananin pers. comm. 2017, } \\
\text { new record }\end{array}$ \\
\hline 23 & $\begin{array}{l}13 \text { Aug. } \\
2016\end{array}$ & $\begin{array}{l}\text { Omsk Obl., Omsk City, Park } \\
\text { Imeni 30-Letiya Pobedy }\end{array}$ & $54^{\circ} 57^{\prime} \mathrm{N}$ & $73^{\circ} 21^{\prime} \mathrm{E}$ & 70 & $\begin{array}{l}\text { Poplar planting in the } \\
\text { park, } 1 \text { imago, S.Yu. } \\
\text { Knyazev Photos. }\end{array}$ & $\begin{array}{l}\text { S.Yu. Knyazev } 2018 \text { pers. } \\
\text { comm., new record }\end{array}$ \\
\hline
\end{tabular}


Table 1. Continued.

\begin{tabular}{|c|c|c|c|c|c|c|c|}
\hline No. & Date & Location & Latitude & Longitude & $\begin{array}{l}\text { Altitude } \\
\text { (m) }\end{array}$ & Observation & Source \\
\hline 24 & $\begin{array}{l}\text { 6-10 Jul. } \\
2017\end{array}$ & $\begin{array}{l}\text { Tyumen Obl., Nizhnetavdinsky } \\
\text { Distr., Lake Kuchak - Tyumen } \\
\text { State University field station for } \\
\text { training }\end{array}$ & $57^{\circ} 20^{\prime} \mathrm{N}$ & $66^{\circ} 04^{\prime} \mathrm{E}$ & 58 & $\begin{array}{l}\text { Along the road, on as- } \\
\text { pens badly damaged by } \\
\text { L. dispar, into a soil trap, } \\
1 \text { female and } 1 \text { male, V.A. } \\
\text { Stolbov Coll. }\end{array}$ & $\begin{array}{l}\text { Zoological Museum of Tyumen } \\
\text { State University, new record }\end{array}$ \\
\hline 25 & 2 Aug. 2017 & $\begin{array}{l}\text { Tyumen Obl., Vagaysky Distr., } \\
6.5 \text { km NW Komsomol'skiy Settl. }\end{array}$ & $57^{\circ} 18^{\prime} \mathrm{N}$ & $68^{\circ} 58^{\prime} \mathrm{E}$ & 65 & $\begin{array}{l}\text { Pine forest with birch } \\
\text { and aspen, in outbreaks } \\
\text { of } L \text {. monacha, } 1 \text { imago, } \\
\text { I.E. Niznik Observ. }\end{array}$ & $\begin{array}{l}\text { I.E. Niznik pers. comm. 2017, } \\
\text { new record }\end{array}$ \\
\hline
\end{tabular}

\section{Discussion}

Table 1 shows that Calosoma sycophanta significantly has expanded the northeastern edge of its range since the late 1990s (Fig. 3). Previously in the Asian part of Russia only a few records existed in the very south-west of that region and 1 record in the Altai. However, over the last 20 years, 24 new records were made in the plains and an another record for the Altai mountains. In addition, records of this species are becoming more northern, penetrating into the boreal zone. There is also an expansion of the range to the east. Early records of $C$. sycophanta were noted for Kurgan and Tyumen oblasts but since 2009, it has been recorded in the Omsk oblast, and since 2010, in eastern Novosibirsk oblast. The edge of the range has expanded $300 \mathrm{~km}$ to the north and $600 \mathrm{~km}$ to the east. It is probable that soon beetles from the 2 population areas (Eastern European-Trans Ural Mountains populations and Altai) will meet and the range of this species will become connected.

In some of the new locations, the number of individuals of $C$. sycophanta was very high. According M.E. Yurin, to a forest ranger of the Omutinsky Forest District of Tyumen region, in recent years this species occurs very often in the forests of that district (E.S. Bayanov 2016 pers. comm.). This species is now also common in the Kurgan oblast (Balahonova 2009), but no specific occurrence data were given.

The expansion of the range of C. sycophanta area has been noted in other regions as well. In North America, where the species was introduced in 1906 and 1907 to control the gypsy moth, its area continues to expand (Schaefer et al. 1999, Evans 2009). In eastern Kazakhstan (in the eastern part of the range) in recent years, several new records of this species have been noted (Bespalov et al. 2010).

As a reason for the increased number of records and the expansion of the range of $C$. sycophanta, we assume that global climate change is responsible. Earlier, since the edge of the 20th century and beginning of the 21st century, both in Europe and in Western Siberia, many steppe arthropod species, such as Argiope bruennichi (Scopoli, 1772), Mantis religiosa (Linnaeus, 1758), and Phaneroptera falcata Poda, 1761, have expanded their ranges to the north (Liana 2007, Bolshakov et al.

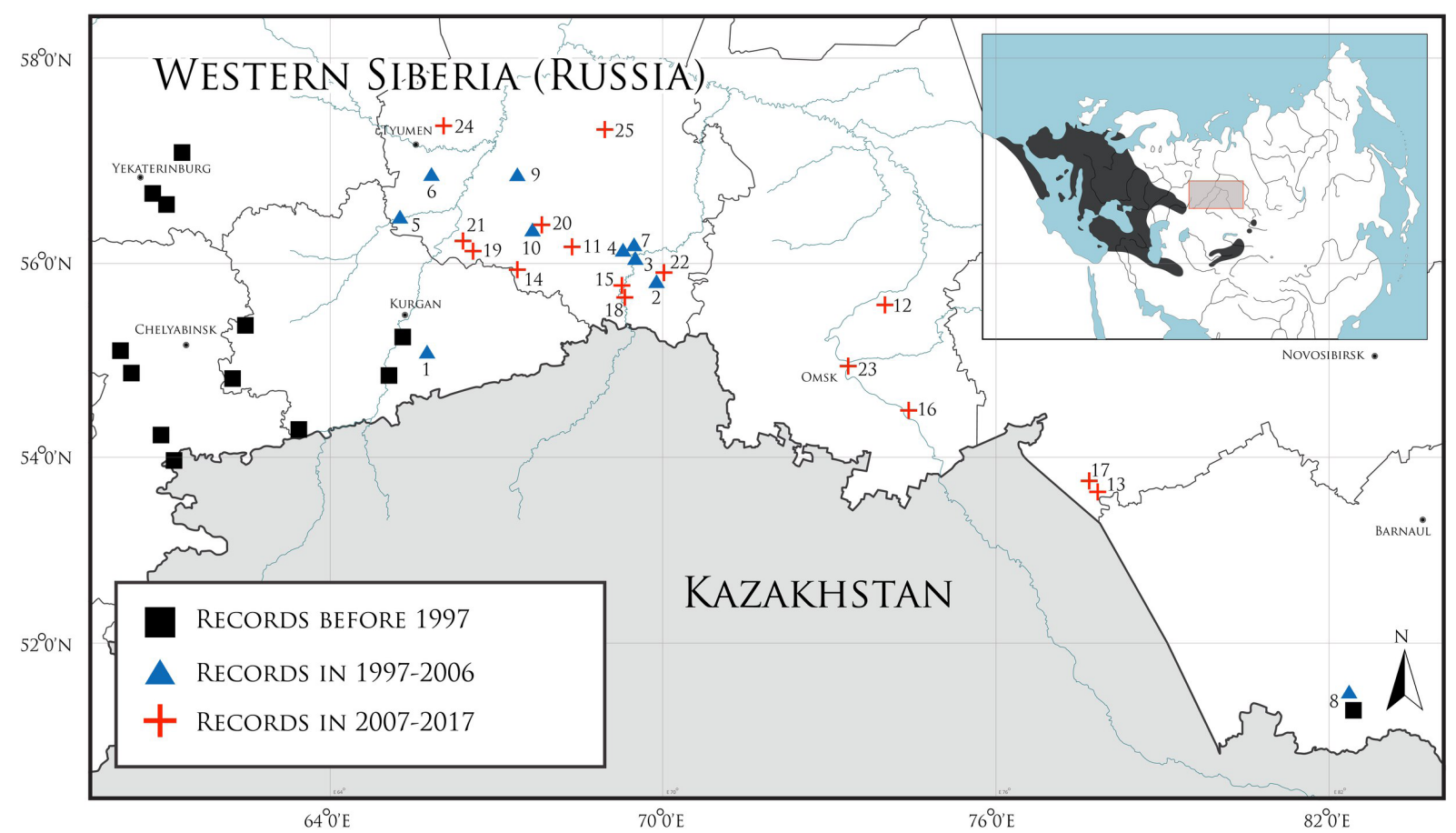

Figure 3. Dynamics of the distribution of Calosoma sycophanta (Linnaeus, 1758) in Western Siberia. Numbers correspond to the records in Table 1. Top right: the area in Palearctic (dark fill) (Krizhanovskii 1983). 
2010, Stolbov et al. 2016), as a result, it is thought, of aridization brought about by climate change. These range expansions look similar to what is now happening with Calosoma sycophanta. The northward expansion of a number of steppe ground beetles, including species of the genus Calosoma, has been noted in recent years in Belarus (Aleksandrowicz 2011), and the increase in the average annual temperature due to global climate change and human economic activity were noted as the main causes.

Calosoma sycophanta is an active predator, an entomophagus, feeding mainly on the larvae of 2 serious forest pests, the Gypsy Moth Lymantria dispar (Linnaeus, 1758) and the Nun Moth L. monacha (Linnaeus, 1758). Kryzhanovsky and Obydov (2001) found that population numbers of Calosoma are fluctuate highly depending on the number of Gypsy Moths. Since the end of the 20th century there has been an increase in the population numbers and ranges of both the gypsy Moth and Nun Moth in Russia, but primarily in Siberia, where they previously were not widespread (Gninenko 2000, Titkina et al. 2013, Yasyukevich et al. 2013).

Most of new records of $C$. sycophanta have been made in places of mass outbreaks of moths, at least in the most northerly locations. Thus, in the Kazansky district (record no. 18), a very high abundance of imagines and larvae of C. sycophanta was noted (A.S. Afonin pers. comm. 2016). On repeated visits to the same locality on July 20, 2016 and July 31, 2017, Gypsy Moth numbers were very low, and $C$. sycophanta was not found. The records of C. sycophanta made in 2017 from the vicinity of the Lake Kuchak biostation of Tyumen State University (Nizhnetavdinsky district of Tyumen oblast) are significant in this regard. Since regular entomological monitoring in this area began in 1993 and until 2016, C. sycophanta had not been found. In 2016 a large Gypsy Moth outbreak occurred in this region, which in 2017 caused a mass deformation of the leaves of aspen and birch. In that year, during the outbreak, a male and a female of $C$. sycophanta were found. Unlike most other large ground beetles, C. sycophanta flies well (Kryzhanovsky 1983, Knyazev 2015). This allows this species to quickly follow its main prey object. Thus, we conclude that significant increases in the abundance of $C$. sycophanta and the expansion of its range to the north and east in Western Siberia is indirectly caused by global climate change, because of the expansion of the range of its main prey, the Gypsy Moth.

\section{Acknowledgements}

We thank A.S. Afonin, M.S. Ananin, E.S. Bayanov, D.V. Kalinin, S.Yu. Knyazev, K. Kurochkina, A.I. Levchenko, Dr A.Yu. Levykh, A.V. Litvinov, Dr I.I. Lyubechanskiy, Dr K.V. Makarov, Dr W. Mathar, I.E. Niznik, V.A. Sannikov, S.A. Semyonova, Dr S.S. Tupitzin and Dr E.V. Zinovyev for kindly shared collection specimens, photographs, and data on C. sycophanta.

\section{Authors' Contributions}

VAS, IVK conceived the manuscript, collected data, and wrote and revised the manuscript; DL and PS, collected data and revised the manuscript; SI analyzed the geographical data and prepared the map.

\section{References}

Aleksandrowicz O. 2011. Recent records of steppe species in Belarus, first indications of a steppe species invasion? ZooKeys 100: 475485. https://doi.org/10.3897/zookeys.100.1541

Balahonova VA (2009) The faunistic review of insects of the southern Pritobolie. Bulletin of the Kurgan State Uuniversity, Series "Natural Sciences" 2: 17-20. [in Russian]

Bayanov ES, Khozyainova NV (2015) New habitats of rare plant and animal species in the Uporovsky district of the Tyumen region [Novyye mestonakhozhdeniya redkikh vidov rasteniy i zhivotnykh v Uporovskom rayone Tyumenskoy oblasti]. XIII Zyryanov Readings: Proceedings of the All-Russian Scientific and Practical Conference, Kurgan, 227-228. [in Russian]

Bespalov AN, Dudko RYu, Lyubechanskii II (2010) Additions to the ground beetle fauna (Coleoptera, Carabidae) of the Novosibirsk Oblast: do the southern species spread to the north? Euroasian Entomological Journal 9 (4): 625-628. [in Russian]

Bolshakov LV, Shcherbakov EO, Mazurov SG, Alekseev SK, Ryabov SA, Ruchin AB (2010) Northernmost records of Praying Mantis Mantis religiosa (Linnaeus, 1758) (Mantodea: Mantidae) in European Russia. Eversmannia 23-24: 22-25. [in Russian]

Breuning S (1927) Monographie der Gattung Calosoma Web. (Carab.), I. Koleopterologische Rundschau 13: 129-232.

Evans AV (2009) The forest caterpillar hunter, Calosoma sycophanta, an Old World species confirmed as part of the Virginia beetle fauna (Coleoptera: Carabidae). Banisteria 34: 33-37.

Gashev SN, Sitnikov PS, Khozyainova NV (2002) Activation of regional zoobotanical studies in the course of work on the Red Book of the Tyumen region [Aktivizatsiya regional'nykh zoobotanicheskikh issledovaniy $\mathrm{v}$ khode raboty nad Krasnoy knigoy Tyumenskoy oblasti]. Issues of practical ecology: Materials of the All-Russian Scientific and Practical Conference, Penza, 38-42. [in Russian]

Gninenko YuI (2000) Some ecological changes in Siberian forests: outbreaks of new species. Problems of regional ecology [Nekotoryye ekologicheskiye izmeneniya v lesakh Sibiri: vspyshki chislennosti novykh vidov]. Materials of the All-Russian Conference, Krasnoyarsk, 174-175. [in Russian]

Jacobson GG (1905 - 1915) Beetles of Russia and Western Europe [Zhuki Rossii i Zapadnoy Evropy]. Releases I-XI. The publication of AF Devrien, St. Petersburg, 1024 pp. [in Russian]

Kalinin SS (1985) Terrestrial invertebrates in the feeding of waterfowl and waterbirds of Transurals [Nazemnyye bespozvonochnyye $\mathrm{v}$ pitanii vodoplavayushchikh i okolovodnykh ptits Zaural'ya]. In: Invertebrate fauna of the Urals, Chelyabinsk, 39-59. [in Russian]

Kanat M, Mol T (2008) The effect of Calosoma sycophanta L. (Coleoptera: Carabidae) feeding on the pine processionary moth, Thaumetopoea pityocampa (Denis \& Schiffermüller) (Lepidoptera: Thaumetopoeidae), in the laboratory. Turkish Journal of Zoology 32 (4): 367-372.

Knyazev SA (2015) Forest Caterpillar Hunter Calosoma sycophanta [Krasotel pakhuchiy Calosoma sycophanta]. The Red Data Book of the Omsk Region, Omsk, 63-64. [in Russian]

Kryzhanovsky OL (1981) Calosoma sycophanta. In: Gorodkov KB (eds) Areas of insects in the European part of the USSR: Atlas. Nauka, Leningrad, 20. [in Russian]

Kryzhanovsky OL (1983) Beetles of suborder Adephaga: family Rhysodidae, Trachypachidae; family Carabidae (introduction and overview of the fauna of the USSR) [Zhuki podotryada Adephaga: 
semeystva Rhysodidae, Trachypachidae; semeystvo Carabidae (vvodnaya chast' i obzor fauny SSSR)]. Fauna of the USSR 1 (2). Nauka, Leningrad, 341 pp. [in Russian]

Kryzhanovsky OL, Belousov IA, Kabak II, Kataev BM, Makarov KV, Shilenkov VG (1995) A checklist of the ground-beetles of Russia and adjacent lands (Insecta, Coleoptera, Carabidae). Pensoft Publishers, Sofia-Moscow, 271 pp.

Kryzhanovsky OL, Obydov DV (2001) Forest Caterpillar Hunter Calosoma sycophanta [Krasotel pakhuchiy Calosoma sycophanta]. Red Data Book of the Russian Federation (animals). Astrel, Moscow, 122. [in Russian]

Lagunov AV (2005) Forest Caterpillar Hunter [Krasotel pakhuchiy] The Red Data Book of the Chelyabinsk region: animals, plants, mushrooms. Publishers of the Ural University, Yekaterinburg. [in Russian]

Levykh AYu (2003) To the question of the fauna of insects of the Ishim region [K voprosu o faune nasekomykh Ishimskogo rayona]. West Siberian regional studies. Scientific and informative collection. Ishim, 183-190. [in Russian]

Liana A (2007) Distribution of Mantis religiosa (L.) and its changes in Poland. Fragmenta Faunistica 50 (2): 91-125. https://doi.org/10.31 61/00159301FF2007.50.2.091

Lomakin DE, Menshchikov AG, Sitnikov PS, Sharapova TA (2001) On the criteria for selecting insects for inclusion in the Red Book of the Tyumen Region. New faunal finds [O kriteriyakh otbora nasekomykh dlya vneseniya v Krasnuyu knigu Tyumenskoy oblasti. Novyye faunisticheskiye nakhodki]. Yearbook of the Tyumen regional museum of local lore. 2000. Tyumen, 349-366. [in Russian]

Molchanov AE (1989) Insects [Nasekomyye]. In: Starikov VP, Fedotova KP (Eds) Must save: rare, extinct animals and plants, nature monuments and reserves of the Kurgan region. Chelyabinsk, 104-135. [in Russian]

Obydov D (2010) Two new subspecies of the caterpillar hunter from the genus Calosoma s. str. from Western Siberia and Mongolia (Coleoptera, Carabidae). Lambillionea 110 (1): 62-64.

Schaefer PW, Fuester RW, Taylor PB, Barth SE, Simons EE, Blumenthal EM, Handley EM, Finn TB, Elliott EW (1999) Current distribution and historical range expansion of Calosoma sycophanta (L.) (Coleoptera: Carabidae) in North America. Journal of Entomological Science 34 (3): 339-362. https://doi.org/10.18474/0749-800434.3.339

Sitnikov PS (2013) New finds of rare insects from the Red Book of the Tyumen region [Novyye nakhodki redkikh nasekomykh iz Krasnoy knigi Tyumenskoy oblasti]. Materials to the second edition of the Red Data Book of the Tyumen Region. TyumenNIIgiprogaz, Tyumen, 95-100. [in Russian]

Stolbov VA, Kuzmin IV, Ivanov SA, Kamp J. (2016) Expansion of the arthropod areals in Tyumenskaya and Kurganskaya Oblast's of West Siberia, Russia. Euroasian Entomological Journal 15 (2): 99-103. [in Russian]

Titkina SN, Popov IO, Semenov SM, Yasjukevich VV (2013) Changes in distribution in Russia and neighboring countries of gipsy moth and nun moth (Lymantria dispar L. and Lymantria monacha L., Lymantriidae, Lepidoptera) due to observed climate change and projected ones for XXI century [Izmeneniye rasprostraneniya $\mathrm{v}$ Rossii i sosednikh stranakh neparnogo shelkopryada i Shelkopryada-monashenki (Lymantria dispar L. i Lymantria monacha L., Lymantriidae, Lepidoptera) pod vliyaniyem nablyudayemogo i ozhidayemogo v XXI veke izmeneniya klimata]. The problems of ecological monitoring and modeling of ecosystems 25: 375-394. [in Russian]

Tolstikov AV (2004) Finds of interesting and new species of insects for the fauna of the Tyumen region [Nakhodki interesnykh i novykh dlya fauny Tyumenskoy oblasti vidov nasekomykh]. Slovtsov Readings: Materials of the XVI All-Russian Scientific and Practical Conference. Part 2. Publishing house of Tyumen State University, Tyumen, 30-31. [in Russian]

Tolstikov AV, Kuzmin IV, Stolbov VA (2013) Protected invertebrates of the Tyumen region in the collection of the Zoological Museum of the Tyumen University [Okhranyayemyye bespozvonochnyye Tyumenskoy oblasti v kollektsii Zoologicheskogo muzeya Tyumenskogo universiteta]. Ecology of animals and faunistics: Collection of scientific works of the Department of Zoology and Evolutionary Ecology of Animals. Issue. 9. Publishing house of Tyumen State University, Tyumen, 161-167. [in Russian]

Utkin NA (1999) Protozoa and invertebrates of the Kurgan region. List of known species. Publishing house of Kurgan State University, Kurgan, 363 pp. [in Russian]

Utkin NA, Balahonova VA (2012) Forest Caterpillar Hunter [Krasotel pakhuchiy]. The Red Data Book of the Kurgan Region. Second edition. Publishing house of Kurgan State University, Kurgan, 121. [in Russian]

Voronin AG (1999) Fauna and complexes of ground beetles (Coleoptera, Trachypachidae, Carabidae) of the forest zone of the Middle Urals (ecology-zoogeographical analysis) [Fauna i kompleksy zhuzhelits (Coleoptera, Trachypachidae, Carabidae) lesnoy zony Srednego Urala (ekologo-zoogeograficheskiy analiz)]. Perm University Publishing House, Perm, 244 pp. [in Russian]

Yashchenko RV, Mityaev ID (2005) Red Data Book of Kazakhstan animals completed [Zavershena Krasnaya kniga zhivotnykh Kazakhstana]. The Steppe Bulletin 17: 32-33. [in Russian]

Yasyukevich VV, Titkina CN, Davidovich EA, Yasyukevich NV (2013) Changes in boundaries of gipsy moth and nun moth (Lymantria dispar and Lymantria monacha, Lymantriidae, Lepidoptera) ranges due to the global warming: a model approach. Zoologicheskii Zhurnal 92 (11): 1377-1382. [in Russian] https://doi.org/10.7868/ S0044513413110135 